\title{
Relação texto-imagem: a resposta de crianças com deficiência visual ao livro ilustrado contemporâneo
}

\author{
Autor: Tássia Ruiz \\ Orientador: Rosane Fonseca de Freitas Martins
}

Resumo: De caráter exploratório, o trabalho apresenta e discute sobre a resposta das crianças com deficiência visual sobre o livro infantil ilustrado, analisando como se estabelecem e dialogam as relações entre texto e imagem no suporte livro sob a perspectiva da não visualidade, principalmente, no que diz respeito à particularidade cognitiva e aos condicionantes específicos da deficiência visual. Justifica-se este estudo pela importância que o acesso a diferentes linguagens (imagem e texto), somadas à função literária da narrativa ficcional podem proporcionar ao leitor mirim, pois além do acesso à imagem e a seu potencial significativo ao leitor, há ainda a possibilidade de incluir a criança com deficiência visual no universo literário, em um campo cujo jogo intricado de linguagens fornece ao leitor uma multiplicidade de sentidos que podem levá-lo ao encontro de novos caminhos para se relacionar com o mundo. O método aqui empregado, entrevista-conversa (SARAMAGO, 2001), questiona crianças cegas e com baixa visão entre 10 e 14 anos do Instituto Londrinense de Instrução e Trabalho para Cegos de Londrina/PR sobre as relações entre a imagem e o texto durante a leitura de duas obras ilustradas adaptadas: Adélia Esquecida e Adélia Sonhadora, ambas selecionadas pela diversidade de recursos gráficos (texturas lisas, flocadas, granuladas, entre outras) utilizados na tradução das imagens para o relevo. Busca-se, sob dois aspectos, comparar equivalências e divergências proporcionadas pela leitura, primeiramente pelas narrativas que dependem de ilustrações para transmitir sua mensagem essencial e as que podem ser facilmente compreendidas apenas pelo texto, a fim de verificar se existe uma integração ou fragmentação de linguagens diante dessa integração imagemtexto no contexto da deficiência visual. Os resultados indicam que a experiência de leitura em cada livro é complexa e singular a cada virar de página. No entanto, as tipologias atuam como parâmetro eficaz para a compreensão das diversas relações entre imagem e texto observadas durante a entrevista e despertam para o vasto campo de possibilidades que há para ser explorado na literatura infantil adaptada. Conclui-se que a imagem tátil e o texto ainda não atingem o status de paridade nas obras adaptadas pesquisadas, sendo necessário ampliar o diálogo e o compartilhamento de informações entre os mediadores dos livros e o público com deficiência visual, de modo que, promova-se não apenas o aumento da qualidade e quantidade de produtos adaptados, como também, um maior exercício crítico para o leitor frente a narrativas interdependentes com imagem e texto.

Palavras-chave: Livros para cegos - Ilustrações, Crianças deficientes visuais - Compreensão na leitura, Ilustrações - Impressão em relevo, Deficientes visuais - Educação 


\title{
Text and images: relations in illustrated book for children with visual impairment
}

\begin{abstract}
Exploratory, the paper presents and discusses the response of children with visual impairment on the illustrated children's book, analyzing how to establish relationships and dialogue between text and image support in the book from the perspective of non-visual, mainly in concerns the cognitive feature and the specific conditions of visual impairment. This study is justified by the importance that access to different languages (image and text ), added to the literary function of fictional narrative can provide the Bantam player, as well as access to imaging and its meaning to the reader, there is still the possibility include children with visual impairment in the literary universe in a field whose intricate set of languages provides the reader with a multiplicity of meanings that can take children's reader to find new ways to relate to the world. The method used here, interview conversation ( SARAMAGO, 2001), questions blind and low vision between 10 and 14 years Londrinense Institute of Education and Work for the Blind of Londrina / PR on the relationship between image and text children during reading two illustrated works adapted: forgotten Adelia Adelia and dreamy, both selected by the diversity of graphical features (smooth textures, flocked , granular, etc.) used in the translation of images for relief. The aim is to compare two aspects equivalences and differences between reading narratives that rely on graphics to convey its essential message and that can easily be understood only by the text in order to verify that an integration or fragmentation of languages that exist on integrating image text - in the context of visual impairment. Results indicate that the experience of reading is complexed in each book, unique to each turn of the page and predominantly verbal. However, typologies act as effective parameter for understanding the various relationships between image and text observed during the interview and awaken to the vast field of possibilities that are there to be explored in the adapted children's literature. We conclude that tactile image and text has not yet reached the status of parity adapted works, it is necessary to increase dialogue and information sharing between the mediators of the books and the public with visual impairments, so that not only promotes increased quality and quantity of suitable products, but also a greater critical exercise for the front of interdependent narratives with image and text reader.
\end{abstract}

Keywords: Braille books, Illustrations, Visually handicapped children, Reading comprehension, Illustrations, Releif printing, Visually handicapped, Education

Dissertação completa disponível em: http://www.bibliotecadigital.uel.br/ document/?view $=$ vtls000189624 